\title{
MetodeKashf dalam Penilaian Hadis: Studi Tashih Hadis di Kalangan Kaum Sufi
}

DOI 10.18196/AIIJIS.2018.0079.27-48

\author{
MUHAM MAD KUDHORI \\ STAI Al-Fithrah Surabaya \\ E-mail: khudhori84@gmail.com
}

\begin{abstract}
$M$ ethod of assessing the soundness of hadith (Prophetic tradition) is not only limited to the rule that hadith's experts formulate and employ. Sufi (M uslim mystical practioner) circles utilize hadith assessment method called kashf (mystical disclosure). This term literally means disclosing or uncovering a hijab (cover). Terminologcally speaking, it means the discl osure of unseen meaningsand truth behind textual appearances. In hadith assessment context, kashf is a method used by Sufis since they do not follow hadith assessment principles and method constructed by hadith experts. The tradition of hadith assessment using kashf method is a new method that emerged after long time ago after Prophet's hadiths were collected. This method emerged between the sixth century until the seventh century of $\mathrm{H}$ ijra. The first figure who applied this method is I bn A rabi $(558.638 \mathrm{H})$. Through kashf assessment method, hadith is considered sahih when it does not contradict shar'ah rules. In adition, the hadith assessment using kashf needs to look at the position and quality of scholars who claim to obtain kashf. In turn, this method makesthe role of sanad (chain of hadith transmission) smaller in terms of hadith determining the reliability of hadith. In kashf, sanad is directly linked to the Prophet SAW, even without having a person narrating a hadith. M oreover, the time interval between a Sufi who obtains kashf and the Prophet is long period of time. Furthermore, kasfh can make Jarh wa Ta'dil (examining reliability of hadith narrators) trivial. The method of kashf is rejected by most of hadith's experts, because it does not hold solid epistemology. The rules are relative, subjective and cannot be objectively defended.
\end{abstract}

K eyword: method, kashf, hadith assessment, sufi.

\section{ABSTRAK}

M etode penilaian hadis ternyata tidak hanya menggunakan kaidah-kaidah yang telah disusun oleh ahli hadis. Ada beberapa metode lain selain yang 
ditetapkan oleh ahli hadis, diantaranya adalah metode penilaian hadis dengan kashf di kalangan kaum sufi. Kashf secara bahasa adalah hilangnya hijab (penghalang). Sedangkan secara istilah adalah tampaknya makna-makna gaib dan hal-hal yang bersifat hakekat yang berada di balik tirai. D alam konteks penilaian hadis, metode kashf berarti metode yang dipakai oleh para tokoh sufi dimana mereka tidak memerlukan lagi kaidahkai dah penilaian hadis yangtelah dibangun oleh ahli hadis. Tradisi penilaian hadis dengan metodekashf merupakan metode baru yang muncul jauh setelah $\mathrm{N}$ abi Saw., bahkan jauh setelah masa ulama hadis mengkodifikasikan hadis-hadis $N$ abi Saw. M etodekashf baru muncul antara abad VI dan VII hijriyah. Tokoh yang pertama kali terdeteksi melakukannya adalah Ibn 'A rabi (558-638 H.). D alam metode kashf syarat yang harus dipenuhi adalah hadis-hadis yang dinilai sahih tidak bertentangan dengan kaidah-kaidah umum syara'. Selain itu penilaian hadis dengan kashf juga harus melihat kedudukan wali yang mendapatkan kashf. M etode penilaian hadis dengan kashf tentu akan mengerdilkan peran dan pentingnya sanad, karena dalam kashf sanadnya langsung kepada Rasulullah Saw. tanpa melalui para perawi hadis. Padahal antara sufi yang mendapatkan kashf dengan Rasulullah Saw. terpaut masa yang sangat jauh. Selain mengerdilkan peranan sanad, metode kashf juga meruntuhkan peranan ilmu Jarh wa Ta'dil yang kaidah-kaidahnya telah dibangun oleh ahli hadis jauh sebelum munculnya metode kashf di kalangan kaum sufi. Kemunculan metode kashf ditolak oleh mayoritas ahli hadis, karena ia tidak bertumpu pada landasan epistemologis yang kuat. Kaidah-kaidahnya bersifat nisbi, cenderung subyektif dan tidak bisa dipertahankan.

Kata kunci: hadis, kashf, metode, penilaian hadis, sufi.

\section{PENDAHULUAN}

Perdebatan tentang penilaian kualitas sebuah hadis sudah muncul sejak zaman dahulu kala di masa para mukharrij (kolektor-kritikus) hadis hidup. Sebut saja misalnya ketika para ahli hadis menilai da'if hadis yang diriwayatkan oleh Muslim dalam kitab Sahih-nya. Hadis yang dimaksud adalah hadis yang menjelaskan bahwa Allah Swt. menciptakan tanah pada hari Sabtu, menciptakan gunung pada hari Ahad, menciptakan pohon pada hari Senin, menciptakan al-makruh (sesuatu yang dibenci) pada hari Selasa, menciptakan al-nur (cahaya) pada hari Rabu, kemudian Allah menebarkan hewan-hewan di dalamnya pada hari Kamis, menciptakan Adam AS setelah waktu ashar pada hari Jum'at pada akhir penciptaan dan pada akhir waktu Jum'at antara ashar dan waktu malam. ${ }^{1}$

Hadis di atas mendapat kritik tajam dari para ulama, seperti Yahya bin Ma'in, al-Bukhari dan yang lainnya. Bahkan al-Bukhari dalam kitabnya alTarikh al-Kabir menyebutkan bahwa hadis di atas merupakan ucapan Ka'b alAhbar. ${ }^{2}$ Pendapat ini juga diikuti oleh al-Baihaqi dan ulama yang lainnya. 
M enurut Ibn Taymiyah, pendapat inilah yang benar, alasannya karena telah mutawatir bahwa Allah SWT menciptakan langit, bumi dan apa-apa yang terkandung di dalamnya dalam waktu enam masa (QS. AI A'raf: 54 dan QS. Yunus: 3).

Sementara itu para ulama yang lain seperti Abu Bakar bin al-Anbari, Abu al-Farj Ibn al-Jawzi dan yang lainnya menilai hadis di atas sebagai hadis sahih. Menurut kelompok ini, hadis di atas tidak bertentangan dengan al-Qur'an. Al-Qur'an mengabarkan bahwa penciptaan langit dan bumi terjadi selama enam hari, sementara hadis di atas menjelaskan penciptaan material yang ada di bumi, seperti tanah, gunung dan yang lainnya. Dengan demikian tujuh hari yang disebutkan oleh hadis di atas bukanlah enam hari yang disebutkan oleh al-Qur'an. Tentang hal ini al Albani berkata: “Hadis ini sedikitpun tidak bertentangan dengan al-Qur'an sebagaimana yang disangka oleh sebagian ulama. Hadis ini hanya memerinci proses penciptaan yang terjadi di bumi dan itu terjadi selama tujuh hari. Keterangan al-Qur'an yang menyebutkan bahwa penciptaan langit dan bumi selama enam hari dan bumi selama dua hari tidaklah bertentangan dengan hadis ini, karena enam hari ini bukanlah tujuh hari yang disebutkan dalam hadis di atas. Hadis ini bercerita tentang periode penciptaan yang terjadi di bumi sehingga bumi tersebut layak untuk ditempati. Dengan demikian hadis ini tidaklah bertentangan dengan al-Qur'an." ${ }^{3}$

Dari fenomena di atas, meskipun para ulama hadis telah merancang sedemikian rupa kaidah-kaidah penilaian kesahihan hadis, ternyata dalam tataran praktik mereka beberapa kali berbeda pendapat dalam menentukan kualitas hadis tertentu. Inilah yang seringkali menimbulkan perbedaan pendapat, khususnya dalam produk hukum Islam yang dihasilkan di kalangan ulama.

Dalam perkembangan selanjutnya, metode penilaian hadis ternyata tidak hanya menggunakan kaidah-kaidah yang telah disusun oleh para ulama hadis. Ada beberapa metode lain -selain yang ditetapkan oleh para ahli hadis- yang dijadikan sebagai cara untuk menilai kualitas hadis. M etode itu diantaranya adalah penilaian kualitas hadis karena hadis itu diterima secara bulat oleh para ulama, karena sesuai dengan al-Qur'an, karena dipakai dalil oleh imam mujtahid, dengan cara kashf, mimpi bertemu Nabi Saw. dan juga karena sesuai dengan fakta-fakta ilmiah modern. ${ }^{4}$

Tak ayal lagi perbedaan metode penilaian hadis ini semakin menambah daftar perebedaan penilain kualitas hadis di kalangan para ulama. Ulama 
fiqh misalnya dengan metodenya berpendapat hadis ini adalah sahih. Namun tidak demikian dengan ulama hadis yang justru menilainya sebagai hadis da'if. Demikian juga ulama sufi misalnya, ketika mereka menggunakan kashf-nya untuk menilai sebuah hadis. Dimana penilaiannya ini sering kali berbeda dengan penilaian ulama hadis.

Tulisan ini tidak akan mengupas semua metode yang telah disebutkan di atas, akan tetapi difokuskan pada kajian metode tashih hadis dengan metode kashf yang banyak dilakukan oleh tokoh-tokoh sufi seperti Ibn 'Arabi, al Shadhili, al Sha'rani dan yang lainnya. Tulisan ini akan berusaha menguak sejarah kemunculan metode kashf, kaidah yang dipakai, serta bagaimana dampak yang ditimbulkannya.

\section{Sejarah Kemunculan Metode Kashf dalam Tashih\}H adis di K alangan K aum Sufi}

Kashf secara bahasa adalah hilangnya hijab (penghalang). Sedangkan secara istilah adalah tampaknya makna-makna gaib dan hal-hal yang bersifat hakekat yang berada di balik tirai. ${ }^{5}$ Dalam konteks penilaian hadis, metode kashf berarti metode yang dipakai oleh para tokoh sufi dimana mereka tidak memerlukan lagi kaidah-kaidah penilaian hadis yang telah dibangun oleh para ulama ahli hadis dalam menilai kualitas hadis. ${ }^{6}$

Pembahasan tentang kashf sebenarnya telah disinggung oleh tokohtokoh sufi terkemuka, seperti al Junayd al-Baghdadi (221-297 H.) dan alQushayri (346-465 H.). Dalam al-Risalah al-Qushayriyyah, al Qushayri menuliskan sebuah bab yang berjudul, al-M uhadarah wa al-M ukashafah wa al-Mushahadah. M enurutnya tingkatan yang bertahap, dimulai dari al-M uhadarah, Ialu al-M ukashafah, kemudian al-M ushahadah. Al-Qushayri mendefinisikan al-M uhadarah sebagai hadirnya hati. Sedangkan alMukashafah adalah hadirnya hati dengan sifat penjelasan yang tidak memerlukan perenungan terhadap dalil. Adapun M ushahadah menurutnya adalah hadirnya Allah yang Maha Haq tanpa adanya keraguan sedikit pun. $^{7}$

Al-Ghazali (450-505 H.) dalam kitabnya Ihya' mendefinisikan ilmu mukashafah sebagai ilmu batin, dimana ia merupakan puncak dari berbagai macam ilmu. Al-Ghazali juga mengatakan bahwa ilmu mukashafah merupakan ilmu yang dimiliki oleh para siddiqin dan muqarrabin. la merupakan pengejawantahan dari nur (cahaya) yang 
nampak di dalam hati tatkala hati tersebut telah bersih dan suci dari sifatsifat tercela, hingga dari nur tersebut dapat tersingkap perkara-perkara banyak yang sebelumnya belum jelas, sehingga dapat mencapai makrifat yang hakiki dengan Dzat Allah Swt., sifat-sifat-Nya yang sempurna, perbuatan-Nya serta hikmah-hikmah-Nya dalam menciptakan dunia dan akhirat. ${ }^{8}$ Lebih lanjut al Ghazali mengatakan bahwa mukashafah adalah makrifat kepada Allah Swt. M ukashafah ini menurut al Ghazali merupakan nur yang diletakkan oleh Allah Swt. pada hati yang bersih dengan ibadah dan mujahadah. ${ }^{9}$

Dalam karyanya yang berjudul Futuh al-Ghayb, 'Abd al Qadir al-jilani dalam al-M aqalah al-Tasi'ah juga menyinggung tentang kashf. Ia mengatakan bahwa dalam diri para wali dan al-abdal dapat tersingkap perbuatanperbuatan Allah Swt. yang dapat menerangkan akal dan melampaui kebiasaan. M enurut al-jilani, hal ini terdiri dari dua bagian; jalal dan jamal. Kashf terhadap jalal (keagungan) Allah Swt. akan mewariskan khauf (rasa takut). Sedangkan kashf terhadap jamal (keindahan) Allah Swt. akan mewariskan ketenteraman. ${ }^{10}$

Sampai masa 'Abd al-Qadir al-Jilani (470-561 H.), belum ditemukan keterangan secara jelas yang menyatakan bahwa kashf dapat digunakan sebagai metode penilaian hadis. Kaum sufi hanya membahas bahwa kashf merupakan anugerah dari Allah Swt. kepada hamba yang dikehendakiNya, berupa tersingkapnya rahasia-rahasia llahi yang tidak nampak bagi orang lain. Memang Abu Yazid al-Bustami (188-261 H.), salah satu tokoh sufi mutaqaddimin pernah secara implisit menyinggung tentang kashf saat ia "mengejek" para ahli hadis yang ia sebut sebagai 'ulama' al-rusum, dimana mereka mengambil ilmu dari orang-orang yang notabenenya telah atau akan mati. Sementara kaum sufi, kata Abu Yazid, mengambil ilmu dari Dzat yang maha hidup. Alkisah saat itu ada orang-orang yang mengajak untuk mengkaji kitab M usannaf 'Abd al-Razzaq karya 'Abd alRazzaq (126-211 H.), ahli hadis kenamaan saat itu, maka Abu Yazid berkata: "Apa keperluan kami kepada 'Abd Razzaq, sedangkan kami mengambil ilmu dari Allah Yang Maha M enciptakan?!"11 Dalam al-Futuhat, sebagaimana yang dikutip oleh Ibn 'Arabi, Abu Yazid pernah mencerca ulama hadis yang ia sebuat sebagai 'ulama' al-rusum dengan berkata: “Kalian semua mengambil ilmu kalian dari mayit, dari mayit (fulan, dari fulan, dimana semuanya telah meninggal). Sedangkan kami mengambil ilmu kami dari Dzat yang Maha Hidup, yang tidak akan mati." Sebagian 
kaum sufi juga berkata: "Hatiku telah bercerita kepadaku dari Tuhanku. Sedangkan kalian (ulama hadis) mengatakan bahwa fulan telah bercerita kepadaku, dari fulan dan fulan. Padahal fulan-fulan itu telah meninggal." ${ }^{12}$ Sampai di sini Abu Yazid al-Bustami hanya berbicara tentang cara mendapatkan ilmu, dimana menurutnya kaum sufi mendapatkan ilmu langsung dari Allah Swt., tanpa melalui perantara manusia. Al-Bustami belum membahas kashf sebagai metode yang digunakan untuk menilai kesahihan sebuah hadis.

Apa yang disampaikan oleh al Bustami di atas tentu akan bertolak belakang dengan pernyataan tokoh sufi yang lain seperti al Junayd alBaghdadi, dimana ia sangat menganjurkan untuk menulis hadis-hadis $\mathrm{Nabi}$ Saw. Dalam salah satu pernyataannya yang terkenal ia berujar: "Barang siapa yang tidak mencatat hadis dan tidak menghafalkan sedikit demi sedikit al Qur'an, maka ia tidak bisa diikuti dalam urusan ini (tasawuf)." ${ }^{13}$ Dalam tradisi tahammul al-hadith (proses penerimaan hadis), mencatat merupakan salah satu cara bagi para periwayat hadis untuk mendapatkan hadis dari guru-guru mereka. ${ }^{14}$ Ini artinya, al Junayd menganjurkan para pengikut tasawuf untuk meriwayatkan hadis dari guru-guru hadis, bahkan hal itu menjadi sebuah keharusan bagi para tokoh tasawuf yang menjadi panutan. Sahal al-Tustari (w. 283 H.), tokoh besar tasawuf yang disejajarkan dengan al-Junayd pernah ditanya, sampai kapan seseorang menulis hadis? la pun menjawab, sampai mati. la juga berkata: "Barang siapa yang menghendaki dunia dan akherat, maka hendaknya ia menulis hadis, karena di dalamnya terdapat manfaat di dunia dan akherat." 15

Beberapa ulama sufi yang menggunakan metode kashf dalam penilaian hadis pada umumnya merujuk kepada tokoh-tokoh sufi setelah 'Abd alQadir al-jilani. Al-Sha'rani (898-973 H.) dalam kitabnya al-Tabaqat al-Kubra, ia menceritakan kisah dari Abu al Mawahib al-Shadhili (820-882 H.) yang berkata: "Saya menghadap Rasulullah Saw., kemudian aku bertanya tentang hadis yang masyhur:

"B erdzikirlah kepada A llah Swt. hingga orang-orang berkata: "(orang itu) gila.".

Sementara dalam Sahih Ibn Hibban disebutkan:

"Perbanyaklah berdzikir kepada A llah Swt. higga orang-orang berkata: "(orang itu) gila.". ${ }^{16}$

Maka Rasulullah Saw. bersabda: "Ibn Hibban benar dalam periwayatannya. Rawi yang meriwayatkan dengan redaksi "udhkuru Allah" juga 
benar, karena aku mengucapkan keduanya. Pada satu kesempatan aku mengatakan "akthiru" dan pada kesempatan yang lain aku mengatakan "udhkuru". ${ }^{17}$

Hadis lain yang dinilai sahih oleh kalangan ahli sufi dengan metode kashf adalah hadis:

"Sahabat-sahabatku laksana bintang. D engan siapa saja kalian mengikuti mereka, maka kalian akan mendapatkan petunjuk."

Tentang hadis ini, al Sha'rani berkata: “Hadis ini, meskipun terjadi perdebatan di kalangan ahli hadis, kualitasnya adalah sahih menurut ahli kashf." 18

Muhammad Yusuf bin Isma'il al-Nabhani (1265-1350 H.) dalam kitabnya Sa'adat al-Darayn mengutip dari Ibn Hajar al-Haytami (909-973 H.), ia mengisahkan bahwa gurunya dan guru ayahnya, al-Shams M uhammad bin Abi al-Hama'il sering kali melihat Nabi Saw. secara langsung, sehingga ia pun ketika ditanya tentang sesuatu, ia tidak menjawabnya hingga disampaikan kepada Nabi Saw. Lalu ia berkata, untuk masalah ini Nabi Saw. mengatakan demikian, sebagaimana yang disampaikan oleh Nabi Saw. kepadanya. Maka berhati-hatilah dari mengingkari hal ini, karena (menging karinya) merupakan racun yang mematikan. ${ }^{19}$

Al-'Ajiluni (1087-1162 H.) dalam pendahuluan kitabnya Kashf al-Khafa' mengatakan:

Penilaian sebuah hadis sebagai hadis palsu, sahih maupun yang lainnya sesungguhnya berdasarkan data yang nampak pada para ahli hadis, baik dari segi sanad maupun yanglainnya, bukan berdasarkan esensi hadis tersebut, karena bisa jadi sebuah hadis dinilai sebagai hadis sahih dalam pandangan ahli hadis sebenarnya adalah palsu maupun da'if, demikian juga sebaliknya. M emang benar, untuk hadis mutawatir dapat dipastikan secara nyata berasal dari Nabi Saw. berdasarkan kesepakatan para ulama. M eskipun keberadaan hadistersebut dapat mengandung beberapa kemungkinan, namun pengamalannya sesuai dengan yang telah ditetapkan oleh para ahli hadis, sehingga darinya dapat digali hukum syara'. Shaykh al-A kbar I bn 'A rabi (558-638 H .) dalam kitabnya al-Futuhat al Makiyyah mengatakan bahwa beberapa hadis dinilai sahih dari jalur para perawinya namun oleh para ahli kashf dinilai tidak sahih, karena telah ditanyakan kepada Rasulullah Saw., hingga diketahui bahwa hadis tersebut adalah palsu, lalu hadis tersebut ditinggalkan dan tidak diamalkan, meskipun kemudian diamalkan oleh para ahli hadis, karena jalurnya (dianggap) sahih. Sebaliknya, beberapa hadis tidak diamalkan karena jalurnya da'if, karena dalam jalurnya terdapat perawi yang memalsukan hadis, namun sebenarnya hadis itu 
adalah sahih, karena ahli kashf telah mendengarnya dari Rasulullah Saw. ketika manghaturkan hadis tersebut kepada Rasulullah Saw. ${ }^{20}$

Ibrahim al-Bajuri (1198-1276 H.), Grand Syaikh al-Azhar yang menjabat pada tahun 1847-1860 M. dalam kitabnya Tuhfat al-M urid ketika mengomentari hadis tentang dihidupkannya kembali orang tua Nabi Saw., kemudian mereka berdua beriman kepada Nabi M uhammad SAW, lalu kemudian meninggal, mengatakan bahwa barangkali hadis tersebut adalah sahih menurut ahli hakikat dengan metode kashf. ${ }^{21}$

Tentang penilaian hadis dengan kashf ini, al-Suyuti dan al-Nabhani pernah menceritakan sebuah kisah dari sebagian wali. Suatu hari wali tersebut menghadiri pengajian seorang ahli fikih. Saat itu ahli fikih tersebut menyampaikan sebuah hadis. Maka wali itu langsung menegur ahli fikih tersebut dan mengatakan bahwa hadis yang disampaikan adalah batil. Sang ahli fikih pun balik bertanya kepada sang wali, dari mana argumen pendapatnya itu. Maka sang wali berkata: "Ini Rasulullah Saw. berdiri di atas kepalamu. Beliau berkata: "Aku tidak pernah mengucapkan hadis ini." Lalu seorang faqih tersebut mendapatkan kashf hingga dapat melihat Nabi Saw. ${ }^{22}$ Al-Suyuti menyatakan bahwa para imam syariah yang telah lalu menegaskan, termasuk karamah seorang wali adalah ia dapat melihat Nabi Saw. dan berkumpul dengannya dalam keadaan sadar, lalu ia mengambil pengetahuan dan anugerah dari Nabi Saw. Para ulama yang menyatakan demikian dari kalangan madhhab Shafi' i diantaranya adalah al-Ghazali, al-Bazi, al-Taj al-Subki dan al-'Afif al-Yafi'i. Sementara dari kalangan Malikiyyah adalah al Qurtubi, Ibn Abi Hamzah dan Ibn al-Hajj dalam kitabnya al-M adkhal. ${ }^{23}$

Al-Sha'rani dalam pendahuluan kitab al Mizan al-Kubra, sebagaimana juga dikutip oleh al-Nabhani, pernah mengisahkan bahwa ia melihat surat tulisan al-Suyuti (849-911 H.) yang dipegang oleh salah satu muridnya yang bernama Shaykh 'Abd al-Qadir al-Shadhili. Surat itu berasal dari seseorang yang meminta kepada al Suyuti agar ia menolongnya di hadapan Sultan Qayatbay. Dalam surat itu tertulis:

K etahuliah saudaraku, sesungguhnya aku berkumpul dengan Rasulullah Saw. sampai saat ini sebanyak tujuh puluh lima kali secara langsung berhadaphadapan. Seandainya bukan karena kekhawatiranku yang butuh kepada $\mathrm{N}$ abi Saw. karena aku masuk dalam lingkungan raja, niscaya aku akan mendatangi benteng itu dan menolongmu di hadapan sultan. A ku adalah seorang laki-laki yang mengkhidmahkan diri kepada $\mathrm{H}$ adis $\mathrm{N}$ abi Saw. dan aku butuh kepada 
B eliau untuk mentashih kan hadis-hadis yang dida'ifkan oleh ahli hadis dari jalur mereka. Tidak diragukan lagi kemanfaatan hal itu lebih besar dari pada kemanfaatan untukmu wahai saudaraku. ${ }^{24}$

Al-Nabhani juga mengisahkan bahwa Shaykh Muhyiddin Ibn 'Arabi berkata:

"Sungguh aku telah mantashihkan beberapa hadis langsung kepada Nabi Saw. yang didha'ifkan oleh para huffaz (ahli hadis). M aka aku mengambil sabda $\mathrm{N}$ abi Saw. dalam menilai hadis itu dan tidak ada sedikit pun keraguan dalam diriku terhadap yang diucapkan oleh $\mathrm{Nabi}$. Bagiku apa yang diucapkannya adalah bagian dari syariatnya yang sahih. A ku akan mengamalkannya, meski para ulama (hadis) tidak mengikutiku, karena berpegang pada kaidah-kaidah mereka." ${ }^{25}$

Dari keterangan di atas dapat ditarik sebuah kesimpulan bahwa tradisi penilaian hadis dengan metode kashf merupakan metode baru yang muncul jauh setelah Nabi Saw., bahkan jauh setelah masa ulama hadis mengkodifikasikan hadis-hadis Nabi Saw. (abad II dan III hijriyah). M etode kashf baru muncul pada abad ke enam dan tujuh hijriyah. Tokoh yang pertama kali terdeteksi melakukannya adalah Ibn 'Arabi (558-638 H.). Ibn 'Arabi dalam pendahuluan kitabnya Fusus al-Hikam bahkan mengklaim, ia telah bertemu Rasulullah Saw. secara langsung pada sepuluh hari terakhir bulan Muharram $627 \mathrm{H}$. di kota Damaskus. Di tangan Rasulullah terdapat kitab Fusus al-Hikam yang kemudian diberikan kepada Ibn 'Arabi agar disebarkan kepada umat manusia. ${ }^{26}$

Metode penilaian hadis semacam ini tentu menyelisi metode penilaian hadis yang dilakukan oleh ahli hadis, dimana sebuah hadis dinilai sebagai hadis sahih ketika telah memenuhi lima syarat; sanadnya bersambung, rawi yang adil, rawi yang dabit atau rawi yang dabit-nya kurang akan tetapi dikuatkan dari jalur yang lain, tidak shadh dan tidak mengandung 'illat. ${ }^{27}$

\section{Kaidah Tashih H adis D engan Metode K ashf $K$ aum Sufi}

'Adnan 'Abdullah Zuhar, seorang tokoh sufi penganut tarekat Tijaniyah berpendapat bahwa tashih (penilain) hadis dengan metode kashf dan ilham merupakan madzhab yang mu'tabar (diakui) di kalangan kaum sufi, meskipun hal tersebut diingkari oleh kalangan ahli zahir (ahli hadis). Menurutnya, tashih dengan metode kashf ini disebutkan oleh al-'Ajiluni dalam kitabnya Kashf al-Khafa dan al-'Ajiluni mendukungnya. Demikian 
juga al-Ghumari dalam dua kitabnya al-Mughir dan al-Burhan al-Jali. ${ }^{28}$ Hanya saja setelah dilacak dalam kitab al-M ughir dan al-Burhan al-Jali, al Ghumari tidak secara jelas dan detail megupas tentang tashih dengan metode kashf. M ungkin yang dimaksud 'Adnan 'Abdullah Zuhar tentang dukungan al-Ghumari ini adalah saat al-Ghumari dalam al-Burhan menjelaskan tentang pemakaian khirqah (jubah yang dipakaikan seorang guru sufi sebagai bentuk baiat terhadap murid) dalam tradisi sufi yang dilakukan oleh Nabi Saw. kepada para tokoh sufi baik melalui mimpi maupun secara langsung, seperti Abu al-Bayan Basha' bin M uhammad al-Qurashi (w. 551 H.) selaku pendiri tarekat al-Bayaniyyah. Nabi memakaikan khirqah kepadanya secara langsung. Tokoh Sufi lain yang mendapatkan khirqah langsung dari Nabi Saw. adalah Ibrahim al-Matbuli, muridnya, 'Ali al Khawwas dan Abu al Mawahib al Shanawi. ${ }^{29}$

Al-Sha'rani (w. 973 H.) juga mengisahkan pemakaian khirqah secara langsung dari Nabi Saw. ini dalam kitabnya Lawaqih al-Anwar al-Qudsiyyah. la mengatakan bahwa dalam sanad pemakaian khirqah, ia mempunyai jalur dimana antara ia dan Rasulullah Saw. hanya ada dua orang saja, yaitu al-Sha'rani, dari 'Ali al-Khawwas, dari Ibrahim al-Matbuli yang mengambil secara langsung dari Nabi Saw. dan berhadap-hadapan dengan tata cara yang telah diketahui di kalangan kaum sufi dalam alam ruhani. Kemudian kata al-Sha'rani, 'Ali al-Khawwas sebelum meninggal juga mendapatkan khirqah langsung dari Nabi Saw. tanpa adanya perantara sebagaimana gurunya, al-Matbuli. ${ }^{30}$

Al-Sha'rani juga menyebutkan bahwa tokoh sufi banyak yang bertemu dan berkumpul dengan Nabi SAW secara ruhani. Mereka antara lain adalah 'Abd al-Rahim al-Qunawi, Abu al-M adyan al-Maghribi, Abu Sa'ud bin Abi al-'Asha'ir, Ibrahim al-Dasuqi, Abu al-Hasan al-Shadhili, Abu al-'Abbas alMursi, Ibrahim al-M atbuli, Jalaluddin al-Suyuti, Musa al-Zawawi dan tokohtokoh sufi lain yang disebutkan al-Sha'rani dalam kitabnya al-Tabaqat alAw liya'. ${ }^{31} \mathrm{Al}$-Suyuti sendiri yang merupakan seorang ahli hadis yang karyakaryanya di bidang hadis tidak diragukan lagi bahkan mengklaim dirinya telah bertemu dan berkumpul dengan Nabi Saw. secara langsung dalam keadaan sadar dan berhadap-hadapan sebanyak tujuh puluh lima kali. Sementara Abu al-Hasan al-Shadhili dan muridnya, Abu al-'Abbas al-M ursi dan tokoh sufi yang lainnya berkata: "Seandainya Rasulullah Saw. terhalang dariku sekejap saja, maka aku tidak menganggap diriku sebagai seorang muslim." ${ }^{32}$ 
Metode penilaian hadis dengan cara kashf dalam tradisi kaum sufi menurut 'Adnan Zuhar adalah metode yang mu'tamad (dapat dijadikan pegangan, kuat) di kalangan para guru sufi. Dalam beberapa kesempatan para tokoh sufi banyak mengungkapkan, "Hadis ini sahih di kalangan kami (kaum sufi)" atau "Hadis itu sahih secara kashf" dan yang lainnya. 'Adnan Zuhar menguatkan pendapatnya ini dengan pernyataan M uhammad al-Kattani (1290-1327 H.) dalam kitabnya al-Fas al-M akhtum Sharh Surat al-Duha. la berkata: "Sesungguhnya wahyu itu terkadang diberikan kepada para wali, sebagaimana halnya diberikan kepada para nabi, kecuali dalam urusan tashri'. Di antaranya adalah penilaian sahih dan da' if mereka terhadap hadis-hadis yang dinilai berbeda oleh ulama lain." Dengan demikian, hadis-hadis yang terdapat dalam kitab-kitab tasawuf yang dinilai palsu dan lemah oleh para ahli hadis adalah berdasarkan penilaian selain kaum sufi, sesuai dengan madhhab dan kaidah mereka. Bukan berdasarkan metode para tokoh sufi yang mulia. Oleh karena itu, ingkar kepada mereka dari sudut pandang ini merupakan sesuatu yang tidak diperkenankan, selagi hal itu disepakati di kalangan mereka, diamalkan dan dipegang oleh mereka. ${ }^{33}$

M enurut Zuhar, perbedaan penilaian hadis di kalangan kaum sufi dan ahli hadis juga disebabkan oleh faktor lain, yaitu perbedaan dalam menyikapi masalah melihat Nabi SAW dan berkumpul bersamanya secara langsung, sebagaimana yang dialami oleh para tokoh sufi, seperti Ibnu 'Arabi, al-M atbuli, 'Ali al-Khawwas dan yang lainnya. Faktor inilah yang menurut Zuhar menjadi pokok persoalan antara kaum sufi dan ahli hadis dalam menilai sebuah hadis. Faktor penting lainnya yang menyebabkan perbedaan pendapat ini adalah perbedaan dalam memahami ilham, kashf, tahdith dan taklim, dimana hadis-hadis sahih telah menjelaskan bahwa Allah Swt. memuliakan sebagian wali-walinya dengan hal-hal itu. Ini menjadi dalil bagi para tokoh sufi atas kebolehan mendustakan hadis sahih ketika mereka mendapatkan "bisikan" maupun kashf dari Allah Swt. maupun Nabi Saw., sebagaimana kisah yang diceritakan oleh al Nabhani di atas tentang seorang wali yang menghadiri pengajian ahli fikih. ${ }^{34}$

Hanya saja menurut Zuhar, aktifitas tashih dan tad'if di kalangan ahli sufi juga harus memenuhi beberapa syarat. Syarat yang terpenting adalah hadis-hadis yang ditashih tersebut tidak bertentangan dengan kaidahkaidah umum syara'. Selain itu tashih dengan kashf juga harus melihat kedudukan sufi yang mendapatkan kashf tersebut. Kesimpulannya, 
menurut Zuhar, tashih dengan cara kashf di kalangan ahli sufi lebih sahih dari pada tashih yang dilakukan oleh ahli hadis, karena kashf, ilham dan tahdith, meskipun sekelompok ulama menyatakan hal itu bisa salah, namun kesalahannya kecil. Sementara kemungkinan lemah pada hadis-hadis yang ditashih oleh ahli hadis dengan metode yang telah maklum banyak terjadi, sebagaimana diketahui oleh orang-orang yang terbiasa mendalami kitabkitab mereka. ${ }^{35}$

Penilaian hadis dengan metode kashf sebagaimana keteranganketerangan yang telah disebutkan di atas ternyata eksistensinya juga diakui oleh sebagian ahli hadis yang mempunyai kecenderungan tasawuf, seperti al-Suyuti, al-'Ajiluni dan al-Ghumari. Bahkan al-Suyuti sendiri menyatakan, ia butuh kepada Rasulullah SAW untuk mentashihkan hadis-hadis yang dida'ifkan oleh ahli hadis dari jalur mereka. ${ }^{36}$

Namun demikian, diantara mereka terkadang terjadi perbedaan pendapat dalam menilai kesahihan hadis, meskipun mereka sama-sama mengakui legalitas tashih hadis dengan metode kashf. Sebagai contohnya adalah hadis yang berbunyi:

"Barang siapa yang men getahui dirinya, maka ia akan mengetahui Tuhannya."

Berdasarkan penuturan al-'Ajiluni, hadis tersebut menurut Muhyi alDin Ibn 'Arabi, meskipun dari jalur riwayat tidak sahih, namun menurutnya sahih dari jalur kashf. ${ }^{37}$ Sementara al-Suyuti saat mengupas hadis ini dalam kitabnya al-Hawi li al-Fatawi hanya menampilkan pendapat al-Nawawi yang menilai hadis tersebut sebagai laysa bi thabit (tidak tetap, tidak mempunyai sanad), Ibn Tamiyah yang menilai palsu dan Ibn Sam‘ani yang menilai bahwa itu termasuk perkataan Yahya bin Mu'adh al Razi. Al-Suyuti tidak berkomentar terhadap penilaian al-Nawawi, Ibn Taimiyah dan Ibn Sam'ani. Ini artinya al-Suyuti sepakat dengan penilaian para ahli hadis tersebut. ${ }^{38}$

Jadi, pada contoh di atas, al-Suyuti berbeda dengan Ibn 'Arabi dalam menilai hadis tersebut, meskipun keduanya mengakui legalitas kashf sebagai metode untuk menilai hadis. Dalam hal ini Ibn 'Arabi menggunakan kashfnya, sementara al-Suyuti tidak. la mengamini manhaj ahli hadis dalam menilai hadis tersebut. 


\section{Penilaian Hadis Dengan Metode Kashf Menghancurkan Kaidah-K aidah IImu H adis}

Dari paparan di atas, metode penilaian hadis dengan menggunakan kashf yang dilakukan oleh kaum sufi sebenarnya tidak mempunyai landasan epitemologis yang kuat. Metode kashf menyaratkan hadis-hadis yang dinilai sahih dengan metode kashf harus tidak bertentangan dengan kaidah-kaidah umum syariah. Selain itu kapasitas tokoh yang mendapatkan kashf juga harus dilihat, tidak boleh sembarangan mengklaim mendapatkan kashf. Inilah yang tidak bisa dibuktikan secara ilmiah, karena tingkat ketakwaan seorang hamba Allah Swt. tidak bisa diukur dengan ukuranukuran yang tampak. Ketakwaan sebagaimana sabda Nabi Saw. berada di dalam hati dan yang tahu tentunya hanyalah Allah Swt. semata.

Penggunaan metode kashf dengan syarat-syarat tersebut dalam penilaian hadis tentu akan mengkerdilkan peranan ilmu hadis yang telah dibangun oleh para ulama hadis. Kajian tentang sanad dan jarh wa ta'dil menjadi tidak berarti. Padahal kajian tentang sanad mendapatkan perhatian yang sangat besar di kalangan ulama salaf sejak masa sahabat sebagai alat untuk mendeteksi hadis-hadis yang bermasalah.

Dengan banyak bermunculannya hadis-hadis palsu, para sahabat dan tabi' in mengerahkan segala kemampuannya untuk menjaga hadis, hingga mereka sangat memperhatikan masalah sanad dalam menilai kebenaran sebuah hadis. Demikian ini karena sanad pada sebuah hadis diibaratkan seperti nasab bagi seseorang. Tentang hal ini M uhammad bin Sirin berkata:

"M ereka pada awalnya tidak menanyakan tentang isnad, akan tetapi setelah terjadi fitnah mereka berkata: "Sebutkanlah kepada kami nama-nama orang yang meriwayatkan hadis kepada kalian." M aka dilihat kepada yang A hli Sunnah, lalu diambil hadisnya dan dilihat pada yang ahli bid'ah, maka jangan diambil hadis mereka." ${ }^{39}$

Sebelum terjadi pemberontakan terhadap 'Uthman, para sahabat tidak selamanya mengharuskan adanya isnad hadis karena mereka dikenal jujur dan terpercaya. Terlebih karena isnad bukanlah hal baru bagi bangsa Arab. Mereka telah mengetahui hal itu sebelum masa Islam. Mereka sering mengisnadkan kisah-kisah dan syair-syair pada masa jahiliyah. Pembuktian tentang isnad hadis baru diharuskan setelah terjadi pemberontakan pada masa sahabat-sahabat yunior dan tabi'in senior. Terkait dengan hal ini, Imam Muslim meriwayatkan dari M ujahid, ia berkata: 
"Bushayr al-'A dawi datang kepada Ibn 'A bbas, kemudian ia menyampaikan hadis dan mengucapkan, "Rasulullah Saw. bersabda, Rasulullah Saw. bersabda,.." A kan tetapi I bn 'A bbas tampak kurang semangat dalam menerima hadis tersebut dan tidak menghiraukannya. Lalu Bushair bertanya kepada I bn 'A bbas, "Wahai I bn 'A bbas, kenapa engkau tidak memperhatikan dan mendengarkan kepada riwayat yang aku ceritakan, padahal aku menceritakan riwayat itu dari Rasulullah Saw. Lalu Ibn 'Abbas menjawab: "Dahulu ketika ada orang yang kami dengar mengatakan "Rasulullah Saw. bersabda", kami akan cepat-cepat membuka mata dan telinga kami untuk mendengarkannya, akan tetapi ketika manusia sembarangan dalam meriwayatkan hadis, maka kami tidak akan mengambilnya kecuali dari orang-orang yang kami kenal." ${ }^{40}$

Setelah masa sahabat, para tabi'in bertanya tentang isnad dan mengharuskannya. Hal ini dapat dilihat dari kisah yang diriwayatkan oleh Ibn 'Abd al-Barr sebagai berikut:

"'A bd al Warith bin Sufyan bercerita kepada kami, ia berkata: Q asim bin A sbagh bercerita kepada kami, ia berkata: M uhammad bin al-Jahm bercerita kepada kami, ia berkata: Ya'la bercerita kepada kami, dari Isma'il bin A bi K halid, dari al Sha'bi, dari al-Rabi ' bin K huthaym berkata: "Barang siapa yang mengucapkan 'Tidak ada Tuhan yang patut disembah selain Allah, tidak ada sekutu bagi$N$ ya, kekuasaan dan puji hanya milik-N ya, Ia menghidupkan dan mematikan. Ia berkuasa atas segala sesuatu.' sepuluh kali, maka ia seperti memerdekakan budak." Al-Sha'bi berkata: "A ku bertanya kepada al-Rabi' bin K huthaym, siapa yang bercerita kepadamu tentang hadis ini?" al-R abi' bin K huthaim berkata: "'A mr bin M aymun al-A waddi." Lalu aku bertemu 'A mr bin M aymun, maka aku bertanya kepadanya: "Siapa yang bercerita kepadamu tentang hadis ini?" M aka ia menjawab: "'A bd al-Rahman bin A bi L ayla." L alu aku bertemu dengan I bn A bi L ayla, kemudian bertanya kepadanya: "Siapa yang bercerita kepadamu?" la berkata: "A bu A yyub al-A nsari sahabat Rasulullah Saw." ${ }^{41}$

Perhatian para tabi'in dan tabi' al-tabi' in tentang isnad dapat dibuktikan dengan beberapa pernyataan mereka berikut ini. Abu al-'Aliyah berkata: “Kami mendengar sebuah riwayat di Basrah dari para sahabat Rasulullah Saw., kami tidak ridha dengan riwayat-riwayat itu hingga kami berangkat mengunjungi meraka, lalu kami mendengarkan riwayat-riwayat itu langsung dari mulut meraka." 42

Para tabi'in dan tabi' al-tabi' in saling berwasiat untuk mencari isnad. Hisham bin 'Urwah berkata: "Apabila ada seseorang yang menyampaikan kepadamu sebuah hadis, maka tanyalah, dari siapa hadis ini?"43 Sufyan al-Thawri berkata: "Isnad adalah pedang orang mukmin, apabila ia tidak 
mempunyai pedang, maka dengan apa ia akan berperang?" ${ }^{44} \mid \mathrm{bn}$ alM ubarak juga berkata: "Isnad adalah bagian dari agama, seandainya tidak ada isnad, maka seseorang akan berkata semaunya sendiri." ${ }^{45}$ Dari pernyataan-pernyataan di atas, maka jelaslah bahwa para tabi' in dan tabi' al-tabi'in mendalami masalah isnad dan menguasainya seperti mereka menguasai persoalan ilmu hadis lainnya. ${ }^{46}$

Salah satu nikmat Allah SWT yang dianugerahkan kepada umat Islam adalah tersebarnya para sahabat ke berbagai penjuru daerah. Sebagian mereka tercatat sebagai orang-orang yang mempunyai umur yang panjang, sehingga mereka mempunyai peran besar dalam menjaga hadishad is Nabi Saw. Setelah banyak bermunculan dusta atas nama Rasulullah Saw., maka para pencari ilmu mendengarkan hadis-hadis dari para sahabat. Ketika mereka mendengar hadis dari selain sahabat, mereka bergegas untuk mengkonfirmasi apa yang telah mereka dengar itu kepada para sahabat. Para sahabat kemudian menjelaskan kepada mereka mana yang benar dari Nabi Saw. dan mana yang tidak. ${ }^{47}$

Para pencari ilmu banyak yang melakukan rihlah kepada para sahabat untuk meyakinkan apa yang mereka dengar dari para tabi' in di kalangan mereka. Inilah maksud ungkapan Abu al-'Aliyah, “Kami mendengar sebuah riwayat di Basrah dari para sahabat Rasulullah Saw., kami tidak ridha dengan riwayat-riwayat itu hingga kami berangkat mengunjungi meraka, lalu kami mendengarkan riwayat-riwayat itu dari mulut meraka." Bahkan para sahabat melakukan rihlah di kalangan mereka untuk hal ini. Sebagai contoh, Abu Ayyub melakukan rihlah ke Mesir untuk menemui 'Uqbah bin 'Amir, kemudian Jabir bin 'Abdullah melakukan rihlah kepada 'Abdullah bin Anis demi sebuah hadis. ${ }^{48}$

Adapun tabi'in dan tabi' al-tabi'in telah memulai berpindah dan melakukan perjalanan jauh untuk mendapatkan hadis dari orang-orang yang terpercaya dan mempelajari hadis-hadis. Ada yang melakukan perjalanan untuk menemui Abu Darda' hanya untuk mendapatkan satu hadis di Damaskus. Ibn Shihab melakukan rihlah ke Sham untuk menemui 'Ata' bin Yazid, Ibn Muhairiz dan Ibn Haywah. Yahya bin Abi Kathir melakukan rihlah ke Madinah untuk menemui anak-anak para sahabat yang berada di Madinah. Muhammad bin Sirin menuju Kufah untuk bertemu dengan 'Ubaidah, 'Alqamah, dan 'Abd Rahman bin Abi Layla. AlAuza'i melakukan rihlah untuk menemui Yahya bin Abi Kathir di Yamamah, kemudian masuk ke kota Basrah. Demikian juga Sufyan al-Thawri, ia 
melakukan rihlah ke Yaman. ${ }^{49}$ Bahkan seorang tokoh tabi'in Madinah, Sa'id bin al-Musayyab berkata:

"Sungguh aku akan melakukan perjalanan beberapa malam dan beberapa hari untuk mencari satu hadis."

Seringkali para tabi'in dan tabi' al-tabi' in mempelajari hadis secara bersama-sama lalu mereka mengambil hadis yang telah mereka ketahui dan meninggalkan hadis yang mereka ingkari. Para imam hadis pada masa itu benar-benar memiliki sifat wara' dan sangat korektif. Mereka benarbenar hafal hadis sehingga bisa menentukan mana hadis sahih, da'if, dan mana hadis maudu'. Bagi mereka hadis itu tidak bercampur. Mereka mampu membedakan hadis yang buruk dan hadis yang bagus. Tentang hal ini, Sufyan al-Thawri berkata:

"A ku menerima hadis dengan tiga macam; aku mendengar hadis dari seseorang kemudian aku mengambilnya sebagai agama; aku mendengar hadis dari seseorang yang aku tidak mampu menjarhnya, kemudian aku menggantungkan hadisnya; aku mendengar hadis dari seseorangyang tidak aku pedulikan hadisnya, namun aku senang untuk mengetahuinya." ${ }^{151}$

Abu Bakr bin al-Athram mengisahkan bahwa Ahmad bin Hanbal melihat Yahya bin Ma'in di Sana'a' di sebuah zawiyah sedang menulis sahifah Ma'mar dari Aban dari Anas. Ketika ada orang yang melihatnya, maka ia menyimpannya, lalu Ahmad berkata kepadanya: “Engkau menulis sahifah Ma'mar dari Aban dari Anas padahal engkau tahu bahwa itu adalah palsu, lalu apa yang akan engkau katakan jika ada orang yang berkata: "Engkau berbicara tentang Aban, kemudian engkau mencatat hadisnya?" Ibn Ma'in berkata: "Semoga Allah merahmatimu wahai Abu 'Abdillah. Aku menulis sahifah ini dari 'Abd al-Razzaq dari Ma'mar, kemudian aku menghafalkan semuanya. Ketahuilah sahifah itu adalah palsu sehingga tidak ada orang yang datang setelahnya, kemudian mengganti Aban dengan Thabit, Ialu meriwayatkannya dari Ma'mar dari Thabit dari Anas bin Malik. Maka akan aku katakan kepadanya: “Engkau bohong, karena sesungguhnya riwayat itu dari Ma'mar dari Aban bukan dari Thabit!"52

Penjelasan tentang isnad hadis merupakan suatu keharusan, baik bagi orang awam maupun orang yang berilmu. Demikianlah pada masa tabi'in dan tabi' al-tabi' in, isnad muttasil telah menjadi perhatian, sehingga perawi hadis harus menjelaskan sumber hadis yang diriwayatkannya. Sebagian 
dari mereka mengibaratkan hadis tanpa isnad dengan rumah tanpa atap dan tiang penyangga. Dengan mengisnadkan hadisnya, seorang perawi hadis telah lepas dari tanggung jawab. la meyakini kesahihan hadis yang diriwayatkannya jika sanad hadis yang diriwayatkan muttasil sampai kepada Rasulullah Saw. ${ }^{53}$

Kesimpulan yang dapat diambil dari pembahasan ini adalah dengan metode isnad para ulama dapat mendeteksi mana hadis yang betul-betul bersumber dari Nabi SAW dan mana yang tidak. Dengan demikian metode tashih dengan kashf tentu akan mengkerdilkan peran dan pentingnya sanad, karena dalam kashf sanadnya langsung kepada Rasulullah SAW tanpa melalui para perawi-perawi hadis. Padahal antara sufi yang mendapatkan kashf itu terpaut sangat jauh masanya dengan Rasulullah SAW.

Selain mengkerdilkan peranan sanad, metode kashf juga akan meruntuhkan peranan ilmu Jarh wa Ta'dil yang kaidah-kaidahnya telah dibangun oleh para ahli hadis jauh sebelum munculnya metode kashf di kalangan kaum sufi. Pernyataan Ibn Sirin saat banyak terjadi fitnah: "Sebutkanlah kepada kami nama-nama orang yang meriwayatkan hadis kepada kalian." Maka dilihat kepada yang Ahli Sunnah, lalu diambil hadisnya dan dilihat pada yang ahli bid'ah, maka jangan diambil hadis mereka." ${ }^{54}$ menjadi tidak berarti lagi.

Tidak mengherankan jika kemudian 'Abd al-Fattah Abu Ghuddah (19171997) mengkritik habis al-'Ajiluni yang membenarkan metode kashf dalam tashih hadis sebagaimana yang dilakukan oleh Ibn 'Arabi. Abu Ghuddah terheran-heran kepada al-'Ajiluni yang membenarkan tashih dengan metode kashf, dimana hal itu akan menghancurkan ilmu-ilmu ahli hadis, kaidah-kaidah hadis dan agama, hingga urusan penilaian sahih dan da'if yang dilakukan oleh para ahli hadis menjadi sesuatu yang tidak bermakna jika dibandingkan dengan kashf., padahal al-'Ajiluni adalah seorang ulama yang mensharah Sahih Bukhari. Abu Ghuddah pun kemudian mengingatkan agar tidak tertipu dalam masalah ini. ${ }^{55}$

\section{KESIM PULAN}

Kashf sebagai metode penilaian hadis muncul jauh setelah hadis-hadis Nabi Saw. dikodifikasikan. Bahkan dalam literatur kitab-kitab ilmu hadis, metode ini tidak pernah disinggung oleh para ulama hadis, termasuk yang mempunyai kecenderungan Tasawuf, seperti al-Suyuti. Kemunculan 
metode kashf sendiri dapat menghancurkan kaidah-kaidah ilmu hadis yang telah dibangun oleh para ahli hadis. Sistem sanad yang mendapatkan perhatian luar biasa di kalangan ahli hadis dan menjadi kebanggaan umat Islam seolah menjadi tidak bermakna di hadapan para pengguna kashf sebagai metode untuk menilai kesahihan hadis Nabi Saw. Selain menafikan ilmu yang berkaitan dengan sanad, metode kashf juga mengesampingkan peranan ilmu Jarh wa Ta'dil sebagai perangkat keilmuan untuk menguji kethiqahan para perawi hadis.

Kemunculan metode kashf tentu ditolak oleh mayoritas ahli hadis, karena ia tidak bertumpu pada landasan epistemologis yang kuat. Kaidahkaidahnya bersifat nisbi, cenderung subyektif dan tidak bisa dibuktikan secara ilmiah. Penggunaan kashf sebagai metode untuk menilai hadis justru akan menimbulkan problem baru, karena adanya klaim kebenaran sepihak dari tokoh sufi yang mendapatkan kashf. Pada tahap berikutnya sentimen para ahli hadis dan pengikut-pengikutnya kepada kaum sufi akan semakin meningkat, karena dalam merujuk kualitas hadis, kaum sufi tidak menggunakan kaidah-kaidah yang telah ditetapkan oleh ahli hadis yang telah teruji sejak ratusan tahun yang lalu.

Kaum sufi semestinya menyadari bahwa penilaian kualitas hadis merupakan domain para ahli hadis, karena mereka yang berkompeten dalam bidang ini. Li kulli rijal fann, setiap disiplin ilmu pasti ada ahlinya. Dalam bidang penilaian hadis, tentu yang ahli adalah ahli hadis. Jika kaum sufi mau merujuk penilaian hadis pada metode yang dipakai ahli hadis, tentu pandangan para ahli hadis dan para pengikutnya akan berubah. Dengan demikian, harapannya tasawuf akan lebih bisa diterima oleh semua kalangan umat Islam, karena hadis-hadis yang menjadi landasan pemikiran mereka adalah hadis-hadis sahih yang telah ditashih oleh ahli hadis. Wallah A'lam.

\section{CATATAN AKHIR}

1 M uslim bin al-H ajjaj bin M uslim al-N aysaburi, alfami' al Sahih, Vol. 8, (Beirut: Dar al-Jail, t.t.), h. 127.

2 Muhammad bin Isma'il al-Bukhari, al-Tarikh al Kabir, Vol. 1, (t.t.: t.p., t.th.), h. 413-414.

3 Lajnah Fatawa bi al-Shabakah al-sslamiyyah, Fatawa al-Shabakah al Islamiyyah, Vol. 2, (t.t.: t.p., 2009), 2769. Fatwa no. 4 bulan Jumadi Tsani, $1424 \mathrm{H}$.

4 Lihat al-M urtada al-Zayn A hmad, $M$ anahij al-M uhaadditsin fi Taqwiyat al-A hadits al-H asanah wa al-D a'ifah, (Riyad: M aktabah al Rushd, 1994), h. 22-34. 
5 'Ali bin M uhammad al -urjani, al-Fa'rifat, (Beirut: D ar al-Kitab al-'A rabi, 1405 H.), h. 237.

6 al-M urtada al-Zayn A hmad, M anahij al-M uhaadditsin, h. 29-30.

7 'A bd al-A krim al-Q ushayri, al-Risalah al-Q ushayriyyah, Vol. 1, (t.t.: t.p., t.th.), h. 39.

8 Muhammad bin Muhamamd al-Ghazali, Ihya' 'U lum al-D in, Vol. 1, (Beirut: Dar al-M a'rifat, t.th.), h. 19-20.

9 M uhammad bin M uhamamd al-G hazal i, M ukhtasar I hya' 'U lum al-D in, (Jakarta: Dar al-Kutub al-Islamiyyah, 2004), h. 15-16.

10 'A bd al-Qadir al-filani, Futuh al-G hayb, (D aka: M arkazal-f'lam al-'A lami 2014), al-magalah 9.

11 Lihat M uhammad Yusuf al Q ardawi, al-H ayah al-Ruhiyyah fi al-tslam, (Kairo: Maktabah Wahbah, 2009), h. 13.

12 Ibn 'A rabi, al Futuhat al-M akkiysah, Vol. 1, (Beirut: Dar al-Fikr, 2007), h. 632.

13 Al-Khatib al-Baghdadi, Tarikh al-Baghdad, Vol. 14, (Beirut: Dar al-Kutub alIImiyyah, t.th.), h. 401.

14 Lihat M ahmud al-Tahhan, Taysir M ustalah al H adith, (Beirut: Dar al-Fikr, t.th.), 132-136.

15 A hmad bin 'U thman al Dhahabi, Tarikh al-tslam, Vol. 21, (Beirut: Dar alKitab al-Arabi, 1987), h. 187.

16 M uhammad bin Hibban al-Busti., Sahih Ibn H iban, Vol. 3 (Beirut: M u'asassah al-Risalah, 1993), h. 99.

17 'A bd al-Wahhab al-Sha'rani, al-Tabaqat al-Kubra, (Beirut: Dar al-Kutub al'Ilmiyyah, 2013), h. 388

18 'A bd al-Wahhab al-Sha'rani, al M izan al-Kubra, Vol. 1, (Beirut: Dar al-Fikr, t.th.), h. 30.

19 M uhammad Yusuf bin I sma'il al-N abhani, Sa'adat al-D arayn, (Beirut: D ar alFikr, t.th.), h. 422-423.

20 Isma'il bin M uhammad al-'Ajiluni, K ashf al-K hafa', Vol. 1, (t.t.: D ar Ihya' alTurath al-'Arabi, t.th.), h. 9-10.

21 Ibrahim al-Bajuri, Tuhfat al-M urid, (Kairo: Dar al-Salam, 2002), h. 69.

22 Lihat 'A bd al-Rahman al-Suyuti, N uzul 'Isa A khir al-Zaman, (Iskandaria: Dar Ibn Khaldun, t.th.), h. 22. M uhammad Yusuf bin I sma'il al-Nabhani, Sa'adat al-D arayn, (Beirut: Dar al-Fikr, t.th.), h. 432.

23 Ibid., h. 21-22.

24 'A bd al-Wahhab al-Sha'rani, al-M izan al-Kubra, Vol. 1, (Beirut: Dar al-Fikr, t,th.), h. 44. M uhammad Yusuf bin Isma'il al-N abhani, al-Fath al-K abir fi D imn al-Ziyadah ila al-Jami' al-Saghir, Vol. 1, (Beirut: Dar al-Kitab al-'Arabi, t.th.), h. 7-8.

25 M uhammad Yusuf bin Isma'il al-N abhani, Sa'adat al-D arayn, (Beirut: D ar alFikr, t.th.), h. 440.

26 Muhyiddin Ibn 'A rabi, Fusus al-H ikam, (t.t.: D ar al-Kitab al-'A rabi, t.th.), h. 47.

27 Ibn Hajar al-'A sqal ani, al-N ukat 'ala K itab Ibn al-Salah, Vol. 1, (M adinah: 'Imadat 
al-Bahth al-'Ilmi bi al-Jami'ah al-Islamiyyah, 1984), h. 417.

28 'Adnan 'A bdullah Zuhar, Tashih al-H adith 'Inda al-Sadat al-Sufiyyah, (t.t.: t.p., t.th.), h. 6-9.

29 A hmad bin M uhammad bin al-Siddiq al-Ghumari, al-Burhan al-fali fi Tahqiq Intisab al-Sufiyyah ila 'A li, (Kairo: M atba'at al-Sa'adah, 1969), h. 146.

30 'A bd al-Wahhab al-Sha'rani, Lawaqih al-A nwar al-Q udsiyyah, (Beirut: Dar alFikr, t.th), h. 14.

31 'A bd al-Wahhab al-Sha'rani, al-M izan al-K ubra, Vol. 1, (Beirut: Dar al-Fikr, t.th), h. 44.

32 Ibid.

33 'Adnan 'A bdullah Zuhar,Tashih al-H adith 'Inda al-Sadat al-Sufiyyah, (t.t.: t.p., t.th.), h. 6-9.

34 Ibid, h. 8.

35 Ibid., h. 8-9.

36 M uhammad Yusuf bin I sma'il al-N abhani, al-Fath al-K abir fî-D imn al-Ziyadah Ila al-fami' al-Saghir, Vol. 1, (Beirut: Dar al-Kitab al-'Arabi, t.th.), 7-8.

37 Isma'il bin Muhammad al-'Ajiluni, K ashf al-K hafa', Vol. 2, (t.t.: D ar Ihya' alTurath al-'Arabi, t.th.), h. 262.

38 'A bd al-Rahman al-Suyuti, al-H awi li al-Fatawi, Vol. 2, (Beirut: Dar al-Kutub al-'Ilmiyyah, 2000), h. 226.

39 Al-Q adi 'Iyad, Ikmal al-M u'lim, Vol. 1, (t.t.: t.p., t.th.), h. 106.

40 M uslim bin al-H ajjaj al-Naisaburi, Sahih M uslim, Vol. 1, (Beirut: Dar al-Jail, t.th.), h. 10.

41 Ibn 'Abd al-Barr, al-Tamhid Lima fi al-M uwatta' min al-M a'ani wa al-A sanid, Vol. 1, (t.t.: M u'assasat al-Q urtubah, t.th.), h. 55.

42 Ibid, h. 56.

43 Ibn A bi Hatim al-Razi, al-Jarh wa al-Ta'dil, Vol. 2, (Beirut: Dar Ihya' al-Turath al-'A rabi, t.th.), h. 34.

44 Ibn Rajab al-H anbali, Sharh 'Ilal al-Tirmidhi, Vol. 1, (R iyad \}: M aktabah al-Rushd, 2001), h. 366.

45 Al-Khatib al-Baghdadi, al-K ifayah fi 'Ilm al-Riwayah, Vol. 1, (al-M aktabah al'Ilmiyyah, t.th.), h. 393.

46 M uhammad 'Ajjaj al-Khatib, al-Sunnah Q abla al-Tadwin, (Beirut: Dar al-Fikr, 1993), h. 220-223.

47 Muhammad 'Ajjaj al-Khatib,... h. 227.

48 Ibid.

49 Al-H asan bin 'Abd al-Rahman al-Ramahurmuz', al-M uhaddith al-Fasil Baina al-Rawi wa al-Wa'i, (Beirut: Dar al-Fikr, 1404 H.), h. 231-232.

50 M uhammad bin Sa'd al-Basri, al-Tabaqat al-K ubra, Vol. 2, (Beirut: Dar Sadir, 1968), h. 381. Yusuf bin 'A bdillah al-Q urtubi, Jami' Bayan al-'Ilmi wa Fadlihi, Vol. 1, (t.t.: Dar Ibni Hazm, 2003), h. 188.

51 M uhammad 'Ajjaj al-Khatib,... h. 228-229. 'A bdullah bin 'Addi al-jurjani, alKamil fi Du'afa' al-Rijal, Vol. 1, (Beirut: Dar al-Kutub al-'Ilmiyyah, 1997), h. 168. 
52 Al-Khatib al-Baghdadi, al-Jami' li A khlaq al-Rawi wa A dab al-Sami', Vol. 4, (t.t.: t.p., t.th.), h. 319.

53 Ibid., h. 224-226.

54 Al-Q adi 'Iyad, Ikmal al-M u'lim, Vol. 1, (t.t.: t.p., t.th.), h. 106.

55 Lihat komentar Abu Ghuddah dalam 'Ali al-Qari, al-M asnu' fi M a'rifat al$\mathrm{H}$ adith al-M awdu' tahqiq 'A bd al-Fattah $\mathrm{A}$ bu G huddah, (Beirut: M u'assasat al-Risalah, 1978), h. 273.

\section{DAFTAR PUSTAKA}

A hmad, al-M urtada al-Zayn. 1994. M anahij al-M uhaadditsin fi Taqwiyat al-A hadits al-H asanah wa al-D a'ifah. Riyad \}: M aktabah al-Rushd.

'Ajiluni (al), Isma'il bin M uhammad. t.th. K ashf al-K hafa', Vol. 1. t.t.: D ar Ihya'al-Turath al-'Arabi.

'A rabi, M uhyiddin Ibn. t.th. Fusus al-H ikam. t.t.: D ar al-Kitab al-'A rabi. 2007. AlFutuhat al-M akkiyyah. Vol. 1. Beirut: Dar al-Fikr.

Baghdadi (al), al -hatib. t.th. Tarikh al-Baghdad, Vol. 14. Beirut: Dar al-Kutub al'Ilmiyyah.

.t.th. a-Jami' Ii A khlaq al-Rawi wa A dab al-Sami', Vol. 4. t.t.: t.p. .t.th. al-K ifayah fi 'IIm al-Riwayah, Vol. 1. Al-M aktabah al-'IImiyyah.

Bajuri (al), Ibrahim. 2002. Tuhfat al-M urid. Kairo: Dar al-Salam.

Barr (al), Ibn 'A bd. t.th. al-Tamhid Lima fi al-M uwatta' min al-M a'ani wa al-A sanid, Vol. 1. t.t.: M u'assasah al-Qurtubah.

Basri (al), Muhammad bin Sa'd. 1968. A I-Tabaqat al-Kubra, Vol. 2. Beirut: Dar Sadir.

Busti (al), Muhammad bin Hibban. 1993. Sahih Ibn H iban, Vol. 3. Beirut: M u'asassat al-Risaalah.

Dhahabi (al), A hmad bin 'U thman. 1987. Tarikh al--slam, Vol. 21. Beirut: Dar alKitab al-'Arabi.

G hazali (al), M uhammad bin M uhamamd. t.th. Ihya' 'U lum al-D in. Beirut: D ar alMa'rifat.

. 2004. M ukhtasar Ihya' 'U lum al-D in. Jakarta: Dar al-Kutub al-I slamiyyah.

Ghumari (al), Ahmad bin Muhammad bin al-Siddiq. 1969. Al-Burhan alfali fi Tahqiq Intisab al-Sufiyyah ila 'A li. Kairo: M atba'ah al-Sa'adah.

H anbali (al), Ibn Rajab. 2001. Sharh 'Ilal al-Tirmidhi, Vol. 1. Riyad: M aktabah alRushd.

'Iyad, Al-Q adi. t.th. I kmal al-M u'lim, Vol. 1. t.t.: t.p.

Jilani (al), 'A bd AI-Q adi r. 2014. Futuh al-G hayb. Daka: Markazal-I'lam al-'A lami. Jurjani (al), 'A bdullah bin 'A ddi. 1997. Al-Kamil fi Du'afa' al-Rijal, Vol. 1. Beirut: Dar al-Kutub al-'Ilmiyyah.

Jurjani (al), 'Ali bin M uhammad. 1405 H . Al-Ta'rifat. Beirut: D ar al-Kitab al-'A rabi. Khatib (al), M uhammad 'Ajjaj. 1993. al-Sunnah Q abla al-Tadwin. Beirut: Dar alFikr.

Nabhani (al), M uhammad Yusuf bin Isma'il. t.th. Sa'adat al-D arayn. Beirut: D ar al-Fikr. 
.t.th. al-Fath alK abir fi D imn al-Ziyadah Ila al-Jami' al-Saghir, Vol. 1. Beirut: Dar al-Kitab al-'Arabi.

Naisaburi (al), M uslim bin al-H ajjaj. t.th. Sahih M uslim, Vol. 1. Beirut: Dar alfail. Q ardawi (al), M uhammad Yusuf. 2009. Al-H ayah al-Ruhiyyah fi al-tslam. Kairo: Maktabah Wahbah.

Q ari (al), 'Ali. 1978. Al-M asnu' fi M a'rifat al-H adith al-M awdu' tahqiq 'A bd alFattah A bu G huddah. Beirut: Mu'assasat al-Risalah.

Qurtubi (al), Yusuf bin 'A bdillah. 2003. Jami' Bayan al-IIImi wa Fadlih, Vol. 1. t.t.: Dar Ibn Hazm.

Q ushayri (al), 'A bd al-Karim. t.th. al-Risalah al-Q ushayriyyah.

Ramahurmuzi (al), al-H asan bin 'A bd al-Rahman. 1404 H. al-M uhaddith al-Fasil Baina al Rawi wa al-Wa'i. Beirut: Dar al-Fikr.

Razi (al), Ibn Abi Hatim. t.th. alfarh wa al-Ta'dil, Vol. 2. Beirut: Dar Ihya' alTurath al-'A rabi.

Sha'rani (al), 'A bd al-Wahhab. t.th. al-M izan al-K ubra. Beirut: D ar al-Fikr. .t.th. Lawaqih al-A nwar al-Q udsiyyah. Beirut: Dar al-Fikr.

Suyuti (al), 'A bd al-Rahman. t.th. N uzul 'Isa A khir al-Zaman. Iskandaria: Dar Ibn Khaldun. .2000. Al-H awi li al-Fatawi, Vol. 2. Beirut: Dar al-Kutub al-'Ilmiyyah.

Zuhar, 'Adnan 'A bdullah Tashih al H adith 'Inda al-Sadat al-Sufiyyah (t.t.: t.p., t.th. dalam http:/ / www.tidjania.fr/ fikh-tariqa/ 512-2013-05-04-19-07-37 diakses 4 September 2017. 